Supporting Information for

\title{
A New Method for the Synthesis of 2-Hydroxy-3-Nitro-1,4- Naphthoquinones: Application to Regiospecific Preparation of Unsymmetrical Nitrobiquinones
}

\author{
Min $\mathrm{Yu}^{\dagger}$, Helena C. Malinakova* ${ }^{*}$, and Kenneth W. Stagliano ${ }^{\dagger}$ \\ Department of Biological, Chemical and Physical Sciences \\ Illinois Institute of Technology, Chicago, Illinois 60616 and Department of Chemistry, University \\ of Kansas, 1251 Wescoe Hall Drive, Lawrence, Kansas 66045 \\ hmalina@ku.edu
}

Table of Contents

General Experimental Methods

S-2

${ }^{1} \mathrm{H}$ and ${ }^{13} \mathrm{C}$ NMR Spectra S-3-S-18

Assignments of ${ }^{1} \mathrm{H}$ and ${ }^{13} \mathrm{C}$ NMR signals for compounds 15 and 16

S-19-S-20 


\section{General Experimental Methods}

Unless otherwise indicated, all NMR spectra were collected at room temperature in $\mathrm{CDCl}_{3}$ using residual $\mathrm{CHCl}_{3}$ as the internal reference $\left(\delta 7.26 \mathrm{ppm}\right.$ for ${ }^{1} \mathrm{H}$ and $\delta 77.25 \mathrm{ppm}$ for $\left.{ }^{13} \mathrm{C}\right)$. IR spectra were measured in $\mathrm{KBr}$ pellets or neat as thin films on $\mathrm{NaBr}$ plates. Mass spectra were measured under fast atom bombardment $(\mathrm{FAB})$ or electron impact (EI) conditions. Melting points were taken in open capillary tubes and are uncorrected. Thin-layer chromatography (TLC) was performed on $250 \mu \mathrm{m}$ silica gel plates with fluorescent indicator (F-254). Flash chromatography was carried out using 35-70 $\mu \mathrm{m}$ silica gel. Anhydrous $\mathrm{CH}_{2} \mathrm{Cl}_{2}, \mathrm{CHCl}_{3}$ and $\mathrm{CH}_{3} \mathrm{CN}$ were purchased from commercial suppliers and used as received. Unless otherwise specified, all manipulations were carried out under an atmosphere of dry nitrogen using standard Schlenck techniques in oven dried (at least $6 \mathrm{~h}$ at $140{ }^{\circ} \mathrm{C}$ ) glassware. Extracts were dried over anhydrous magnesium sulfate and concentrated under reduced pressure in a rotary evaporator. 


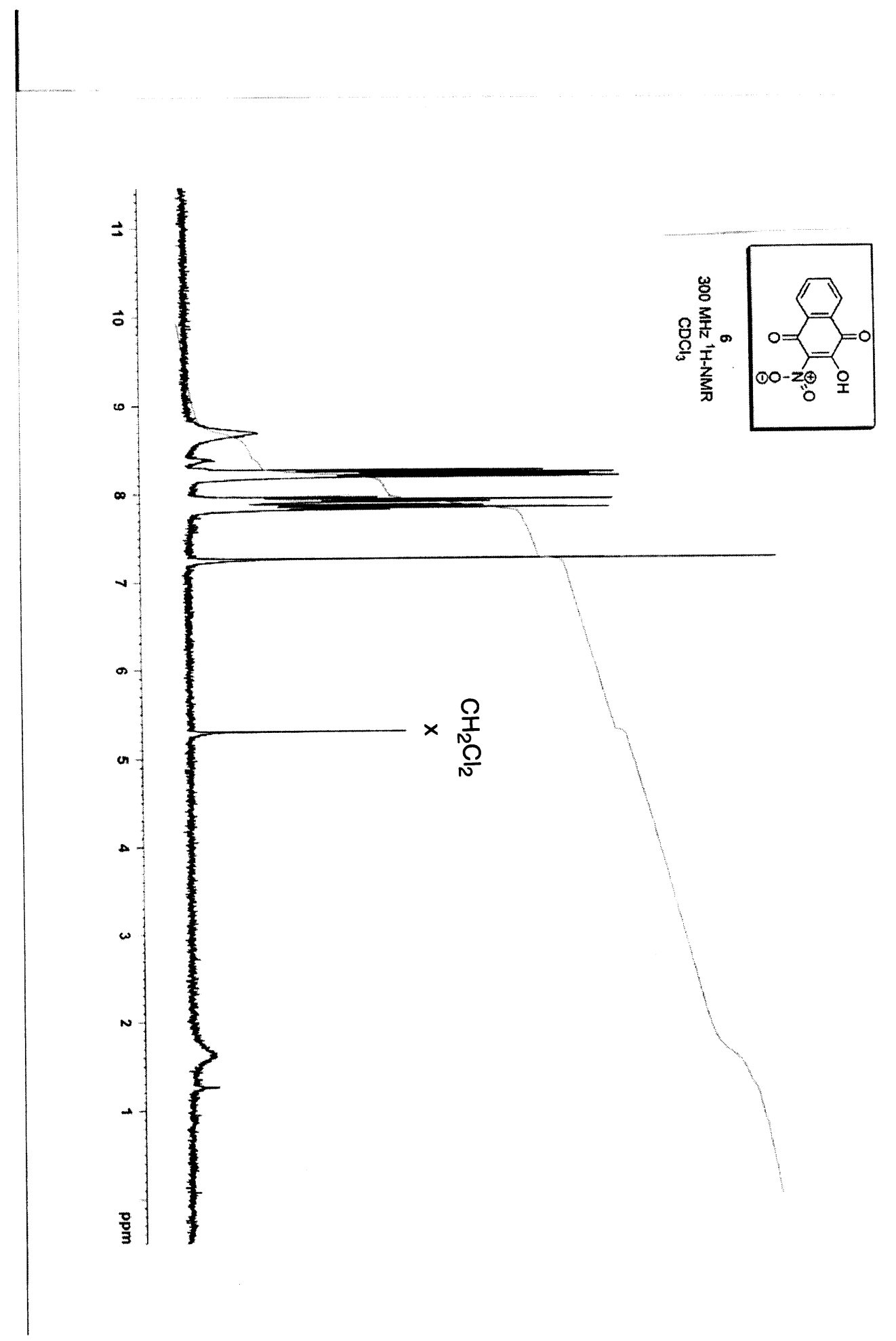

$s-3$ 


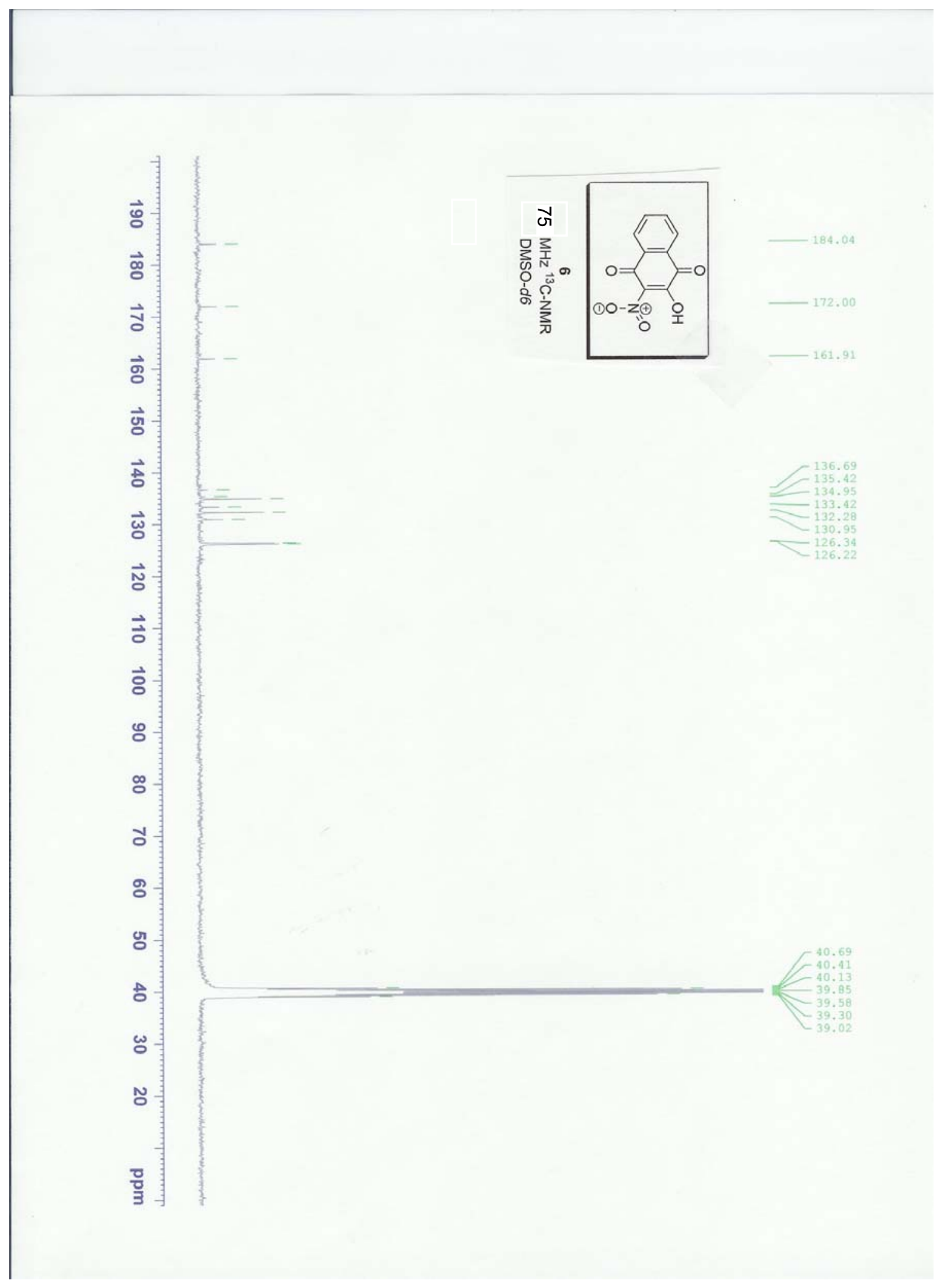




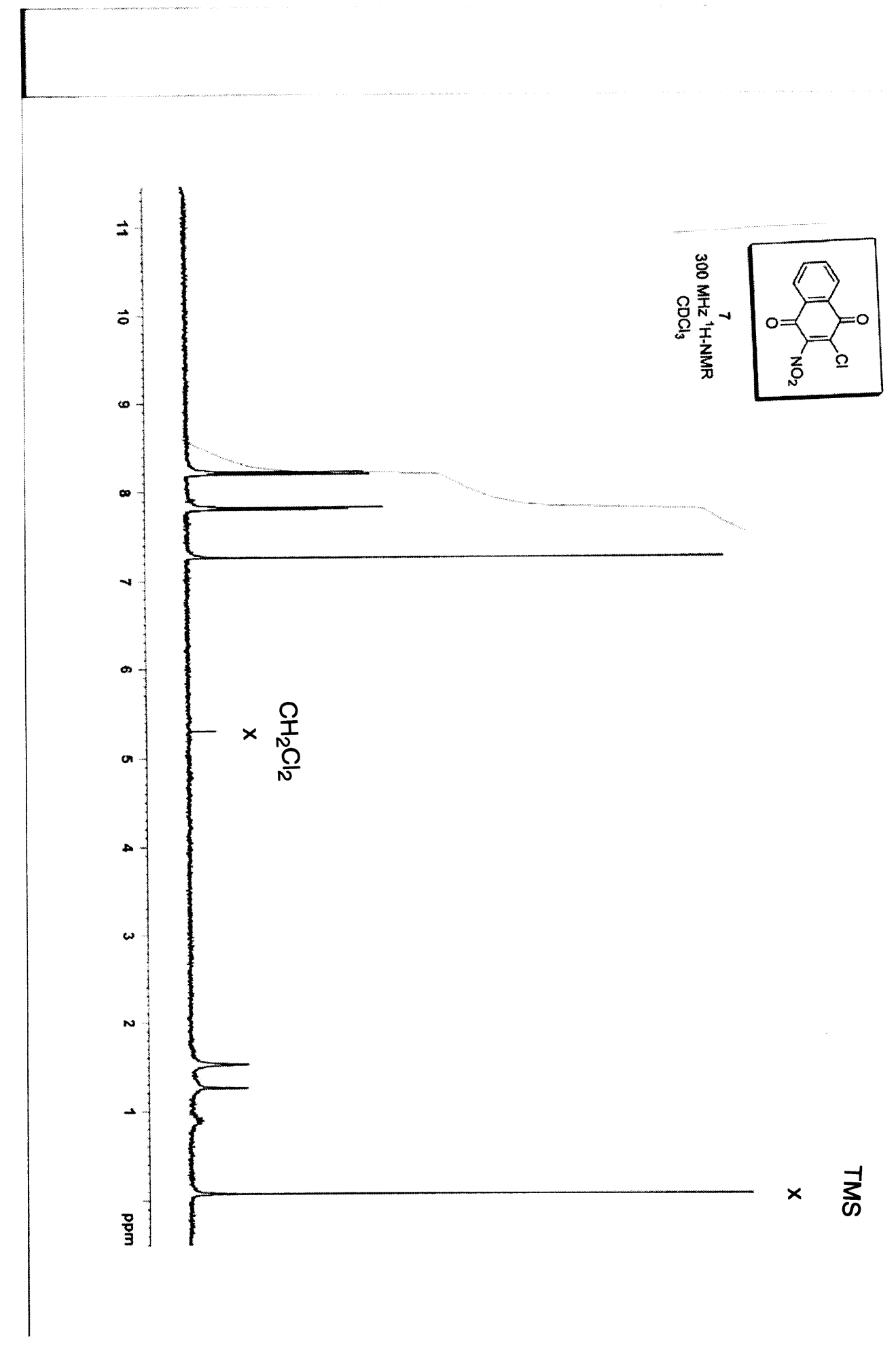

$S-5$ 


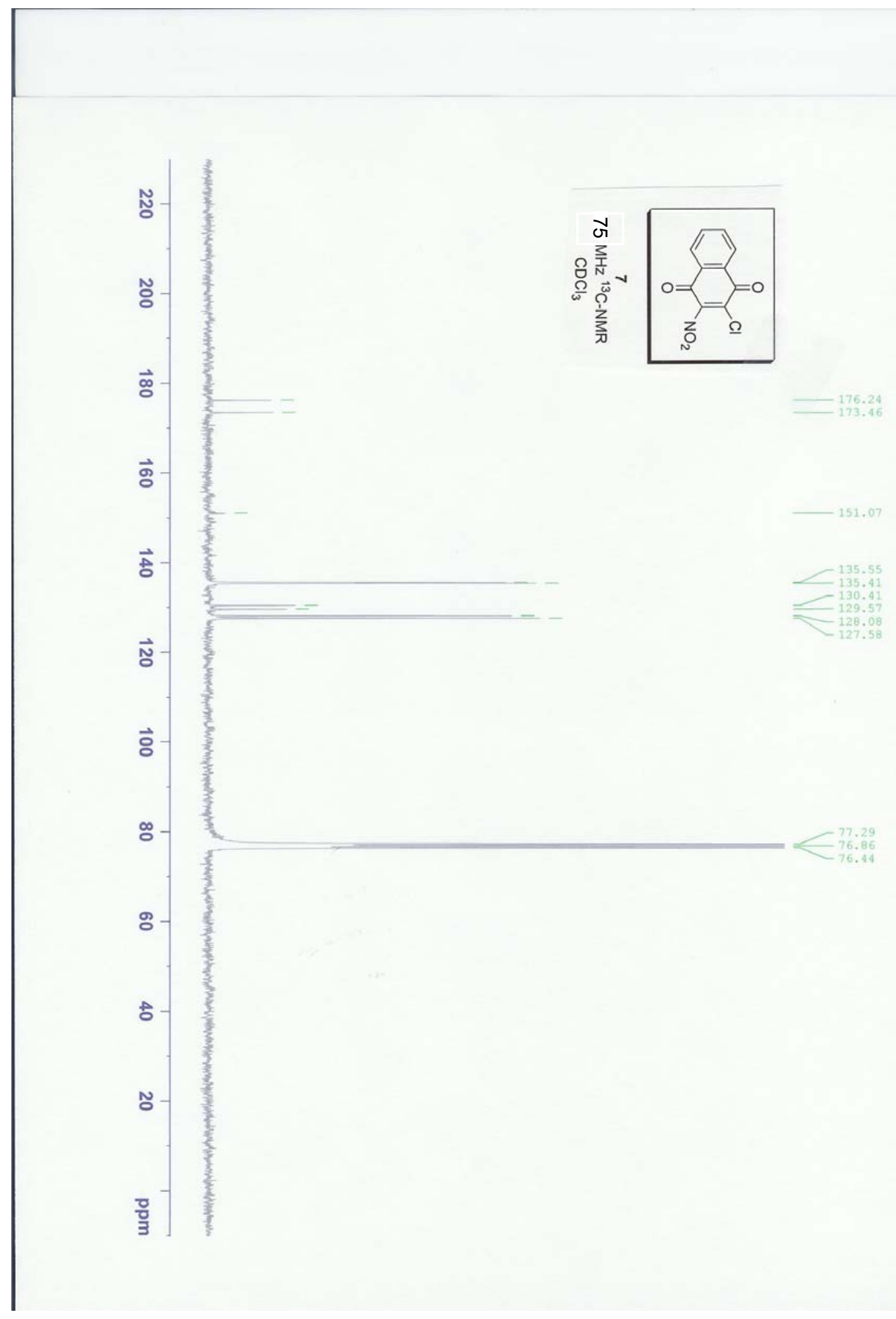




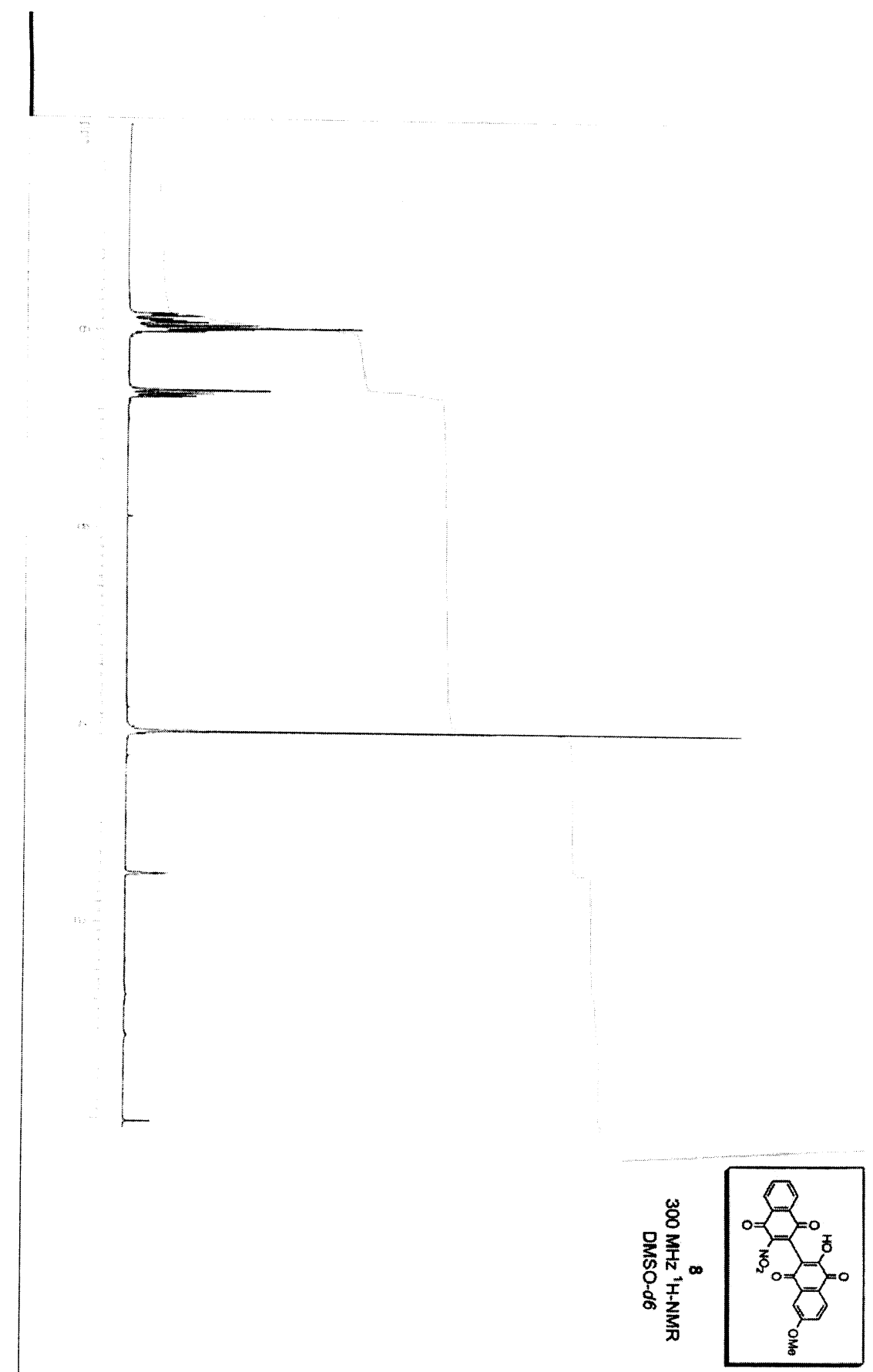

$S-7$ 


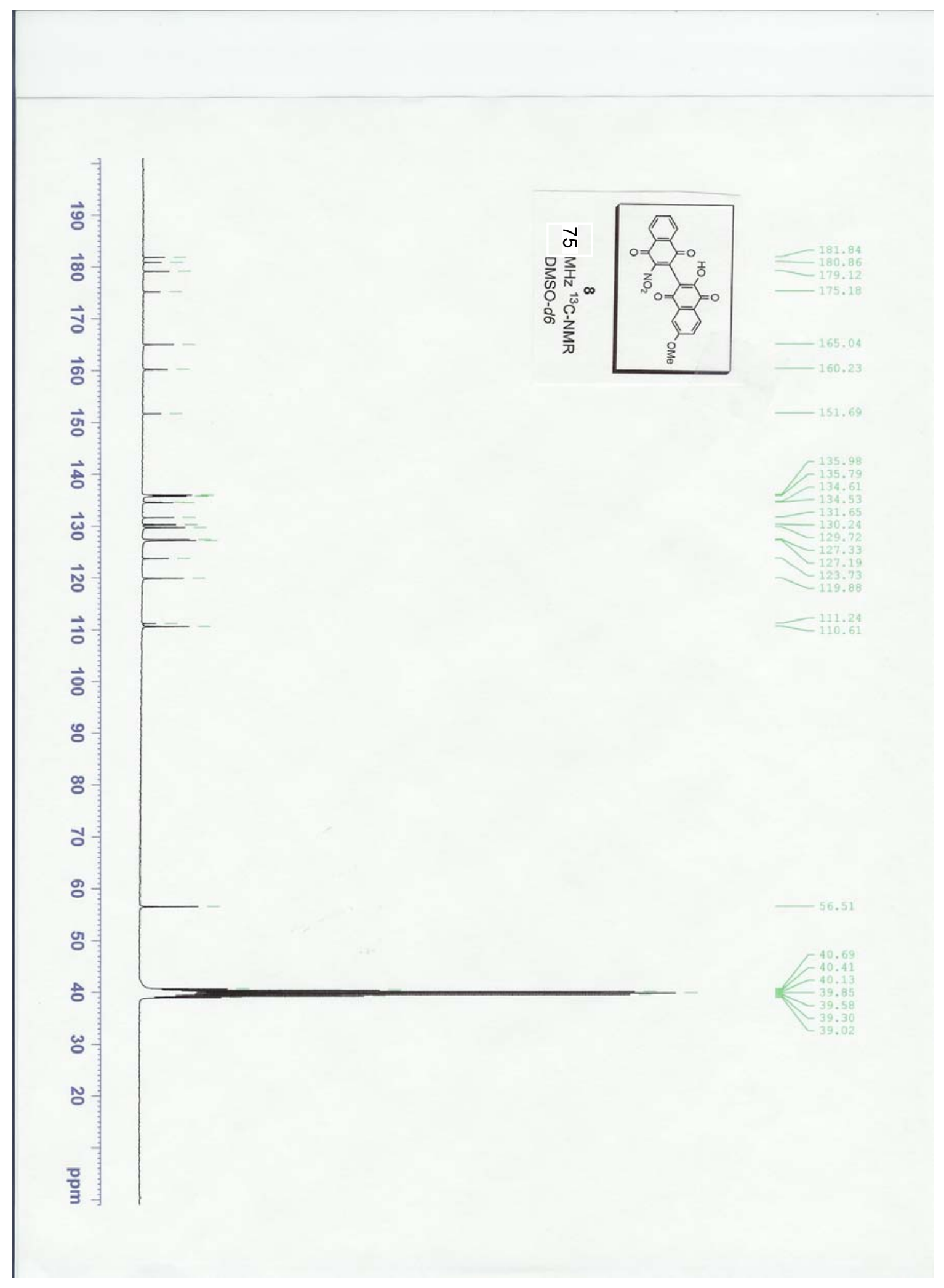




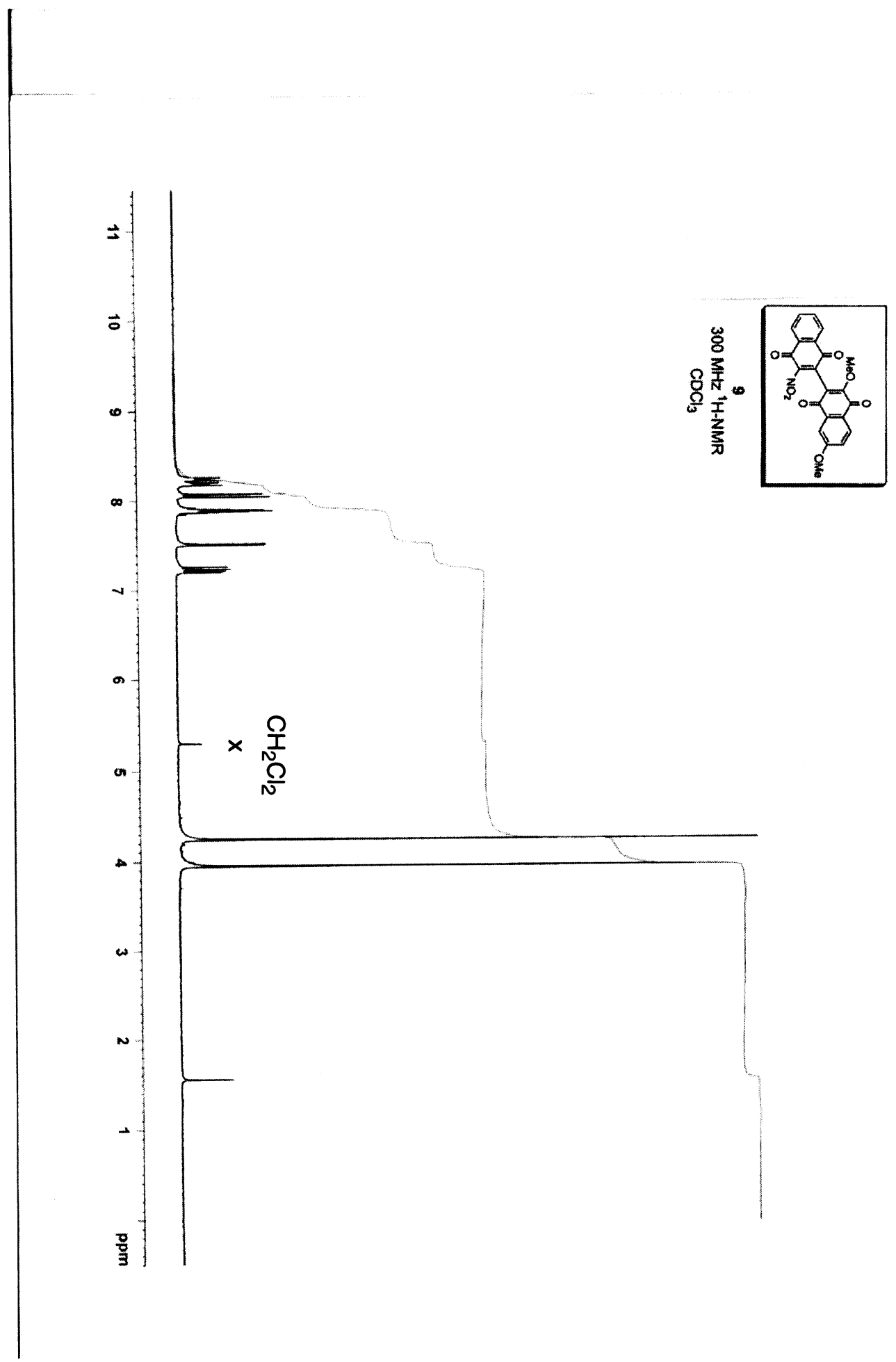

$S-9$ 


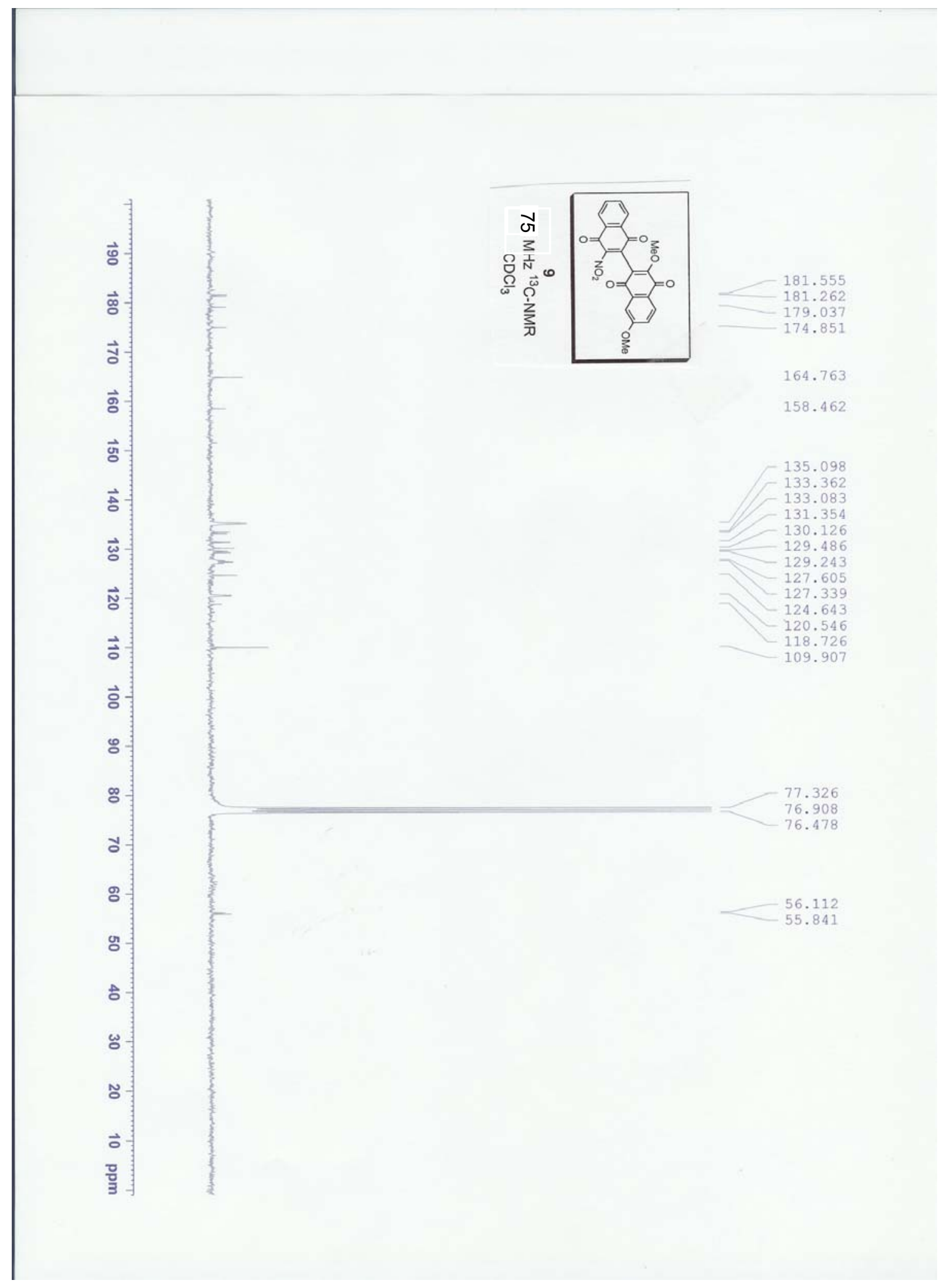

S-10 


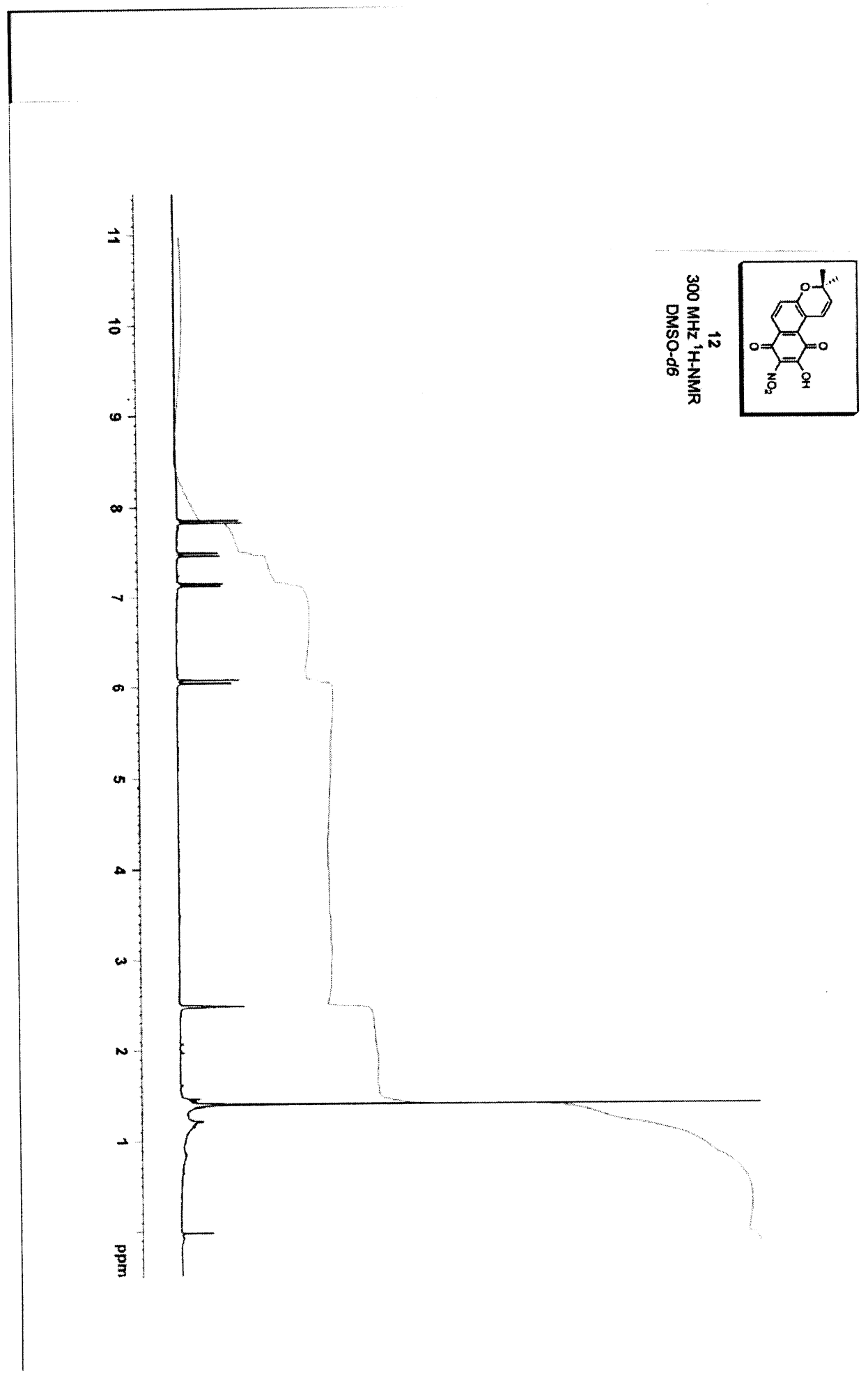

$s-11$ 


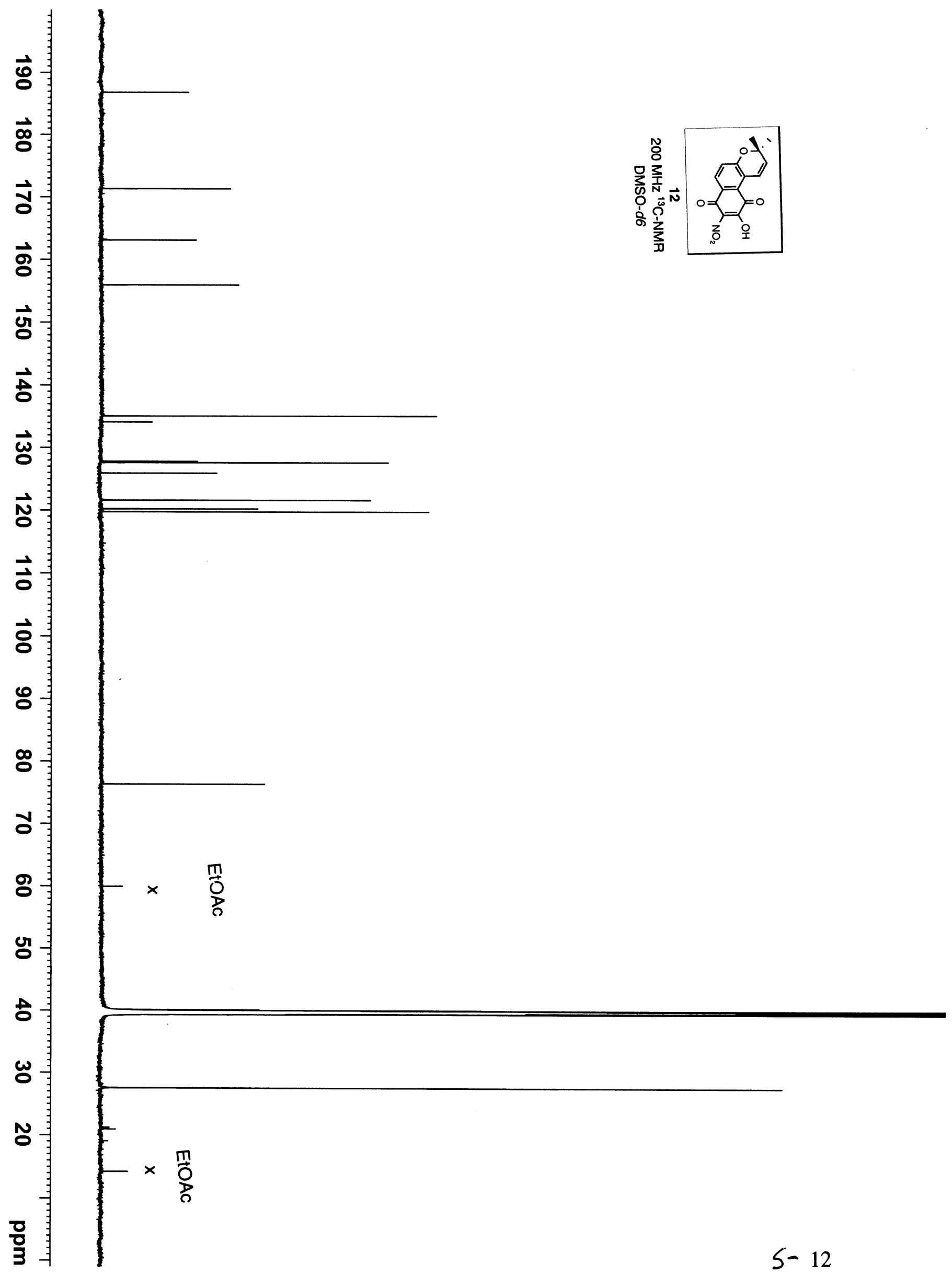




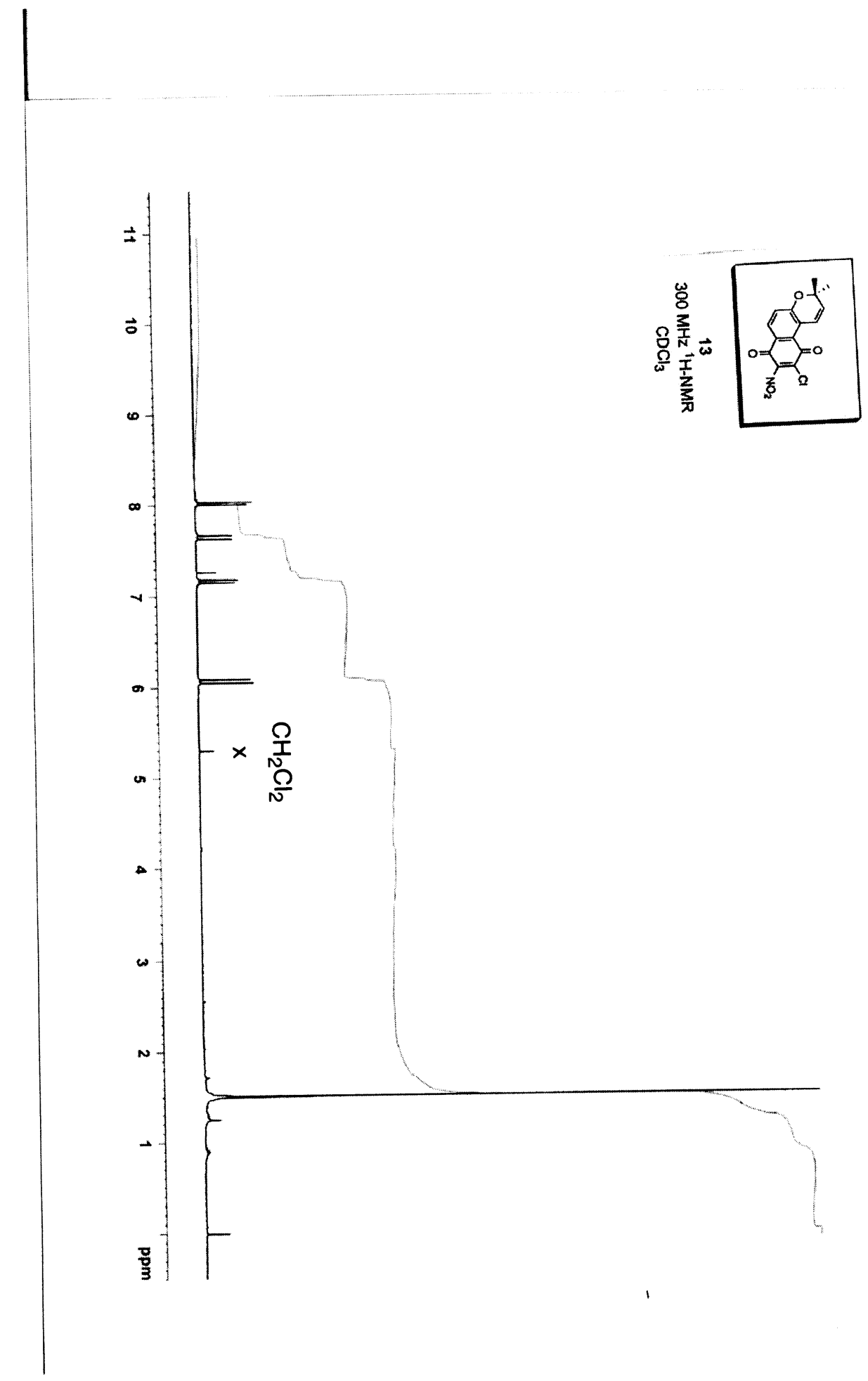




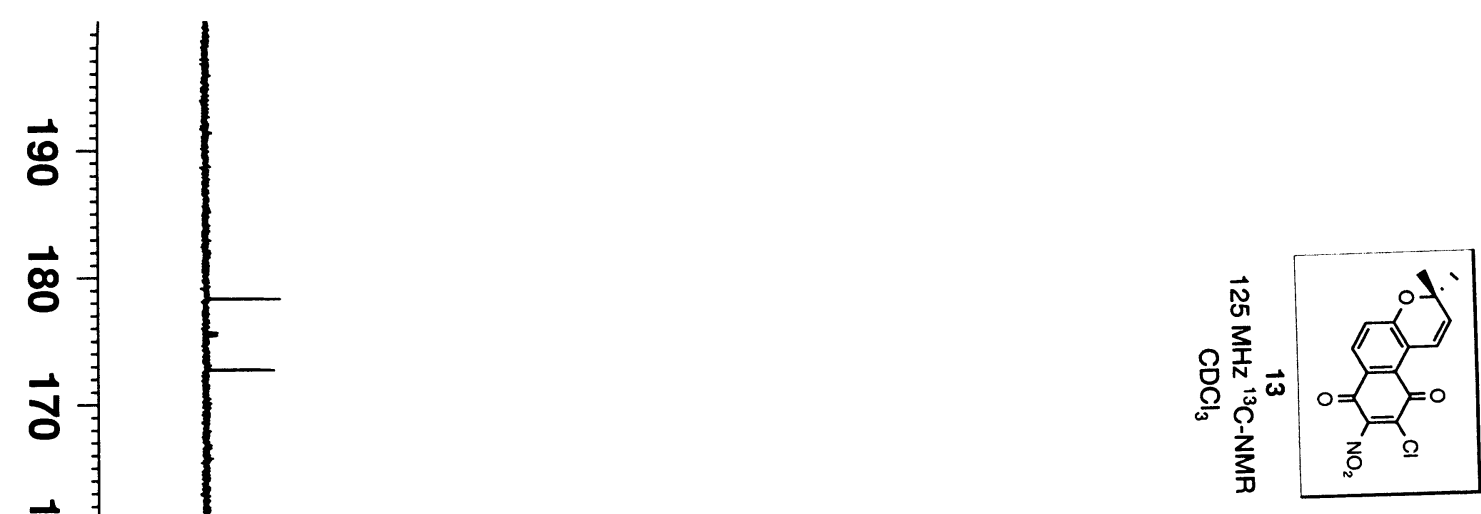

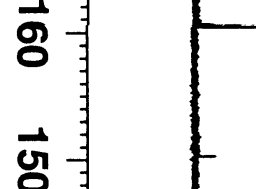

잉

8

$\overline{\mathrm{g}}$

w正

熍专

tे

ᄒ

c

:

a

8

a

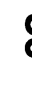

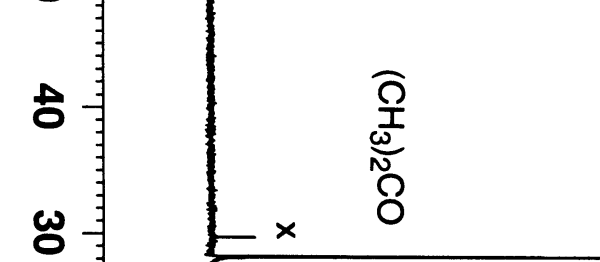

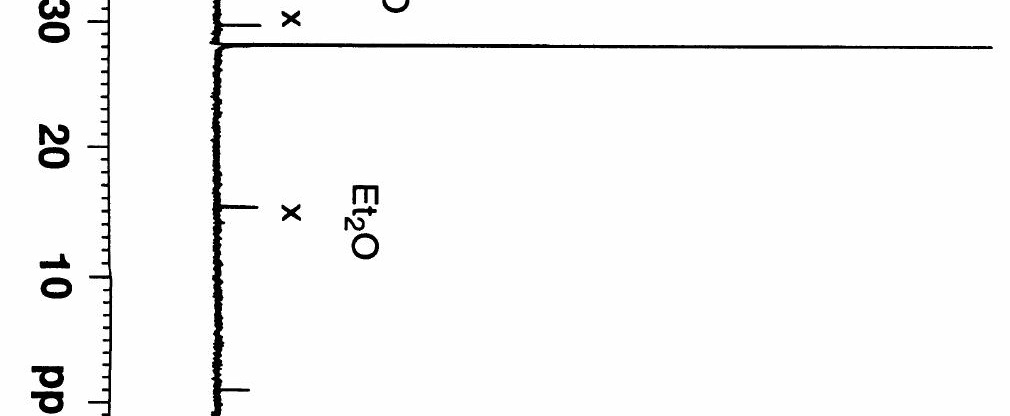




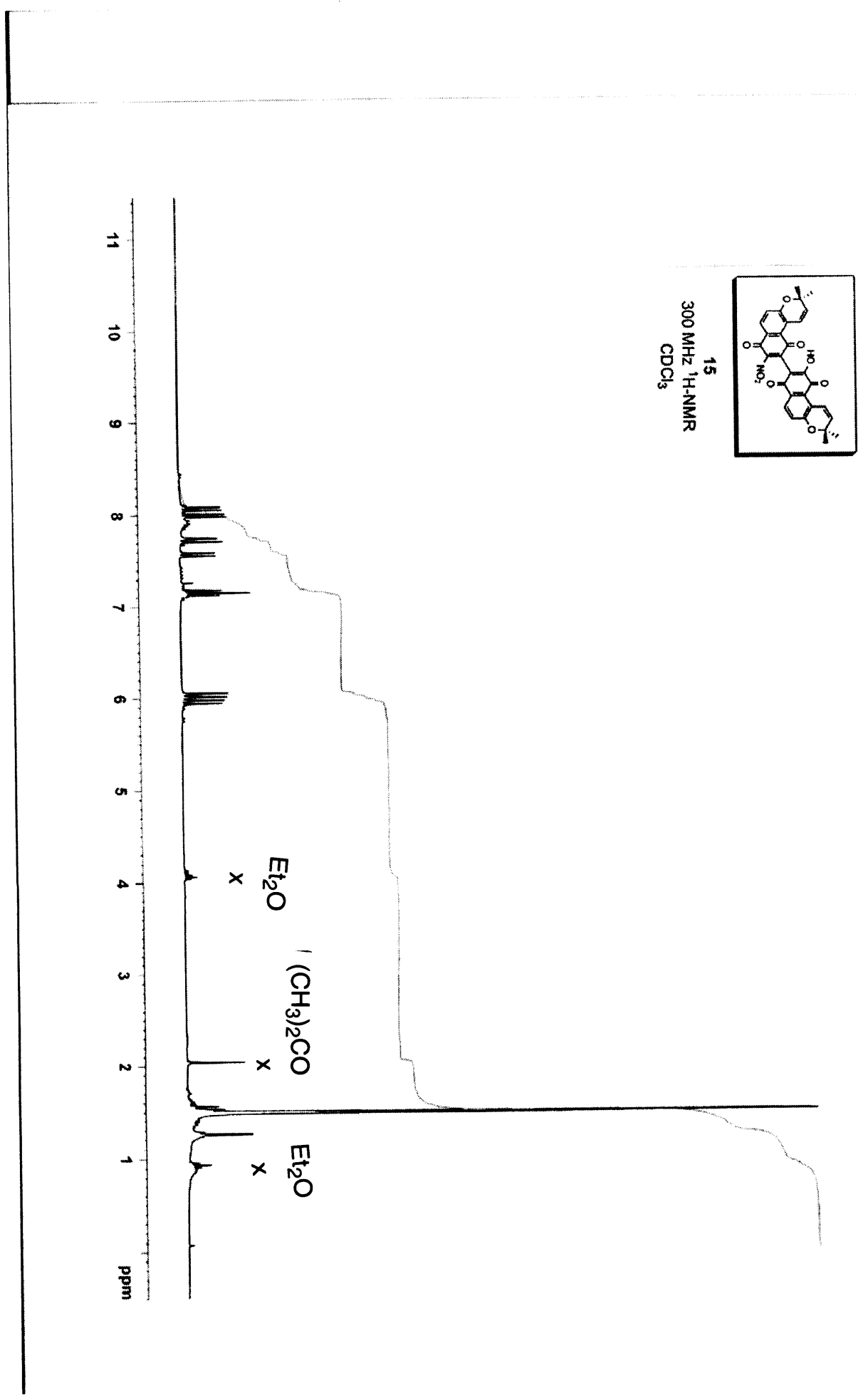




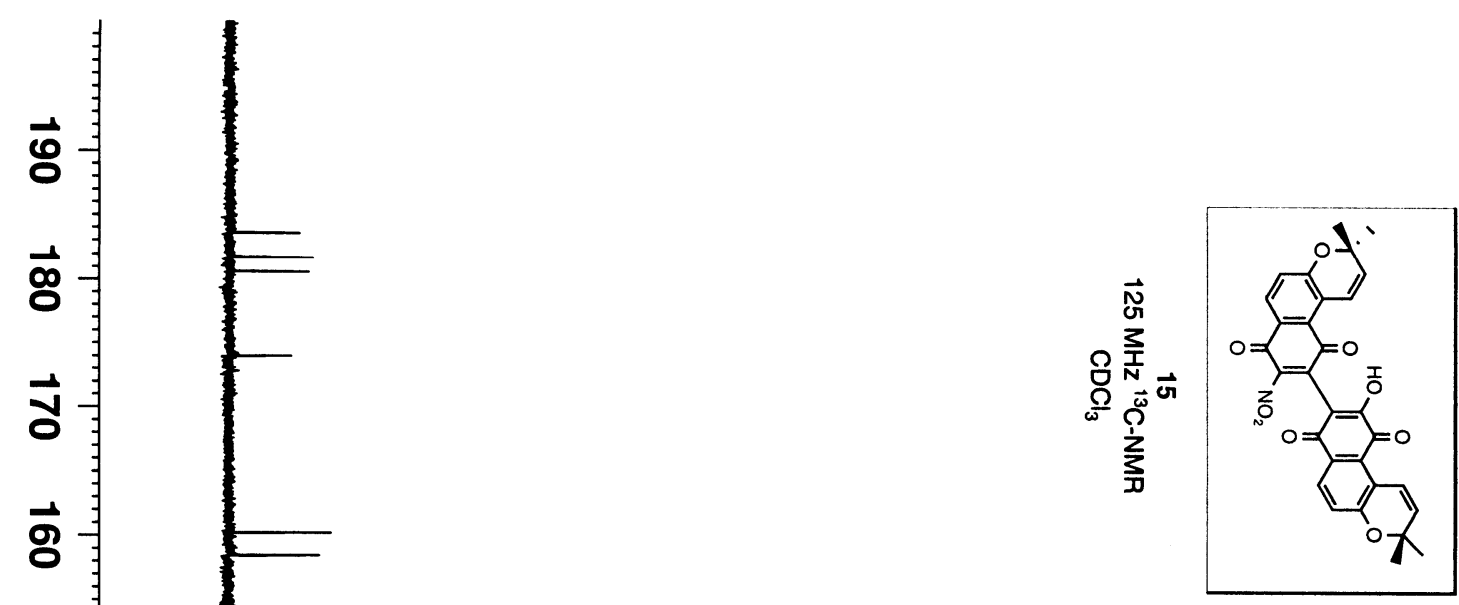

$$
\text { 형 }
$$

$\overrightarrow{\mathrm{g}}$

$\overrightarrow{\mathrm{a}}$

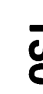

$\overrightarrow{\mathrm{g}}$

$$
\text { 몸 }
$$

ज्ञ

a

흐

8

学

8

잉

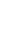

เ

๘

N
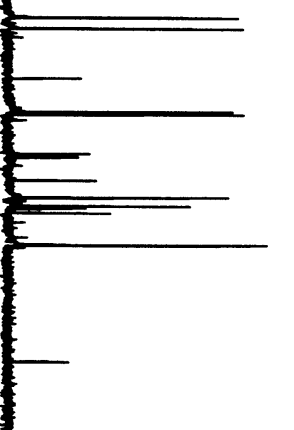


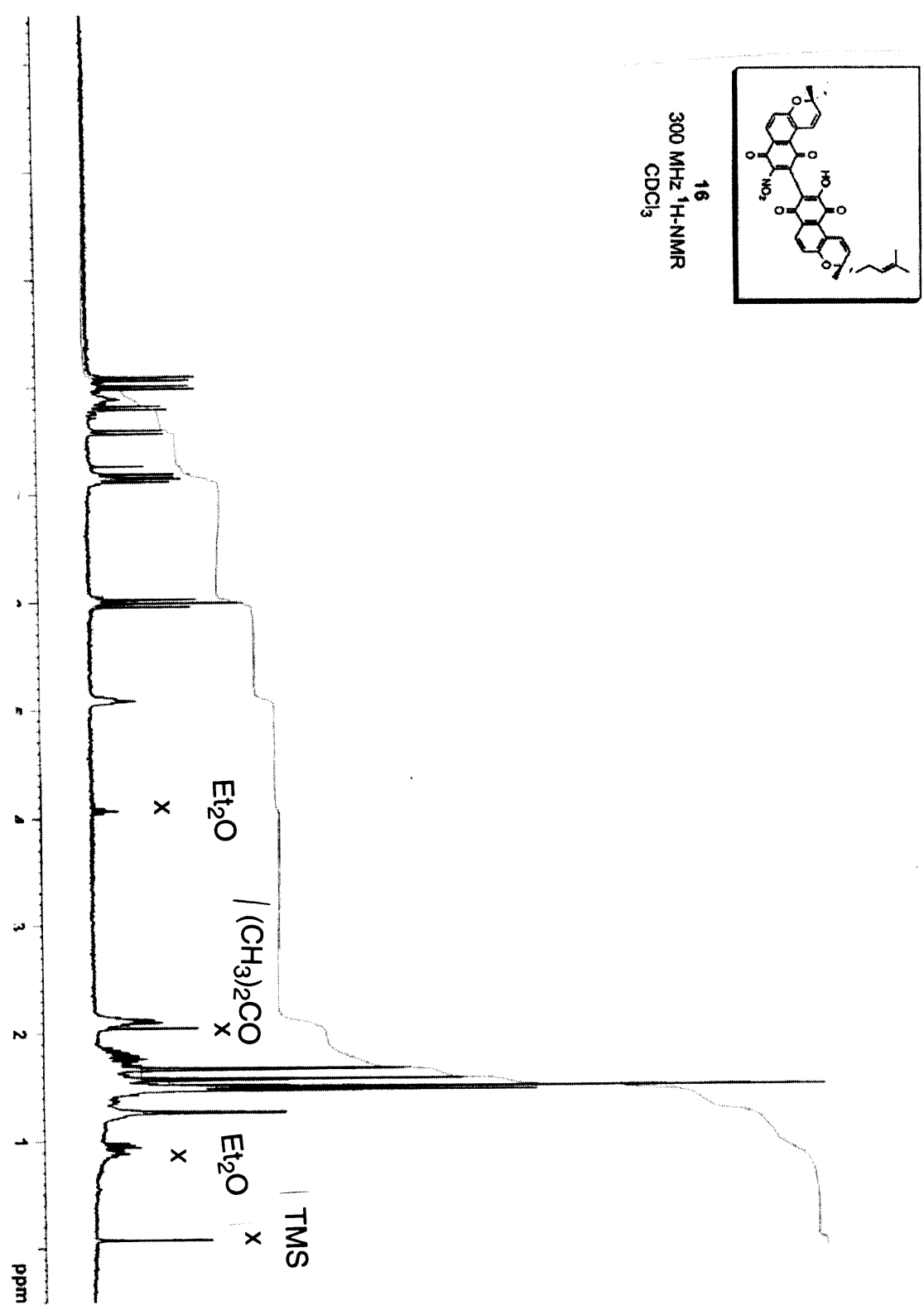




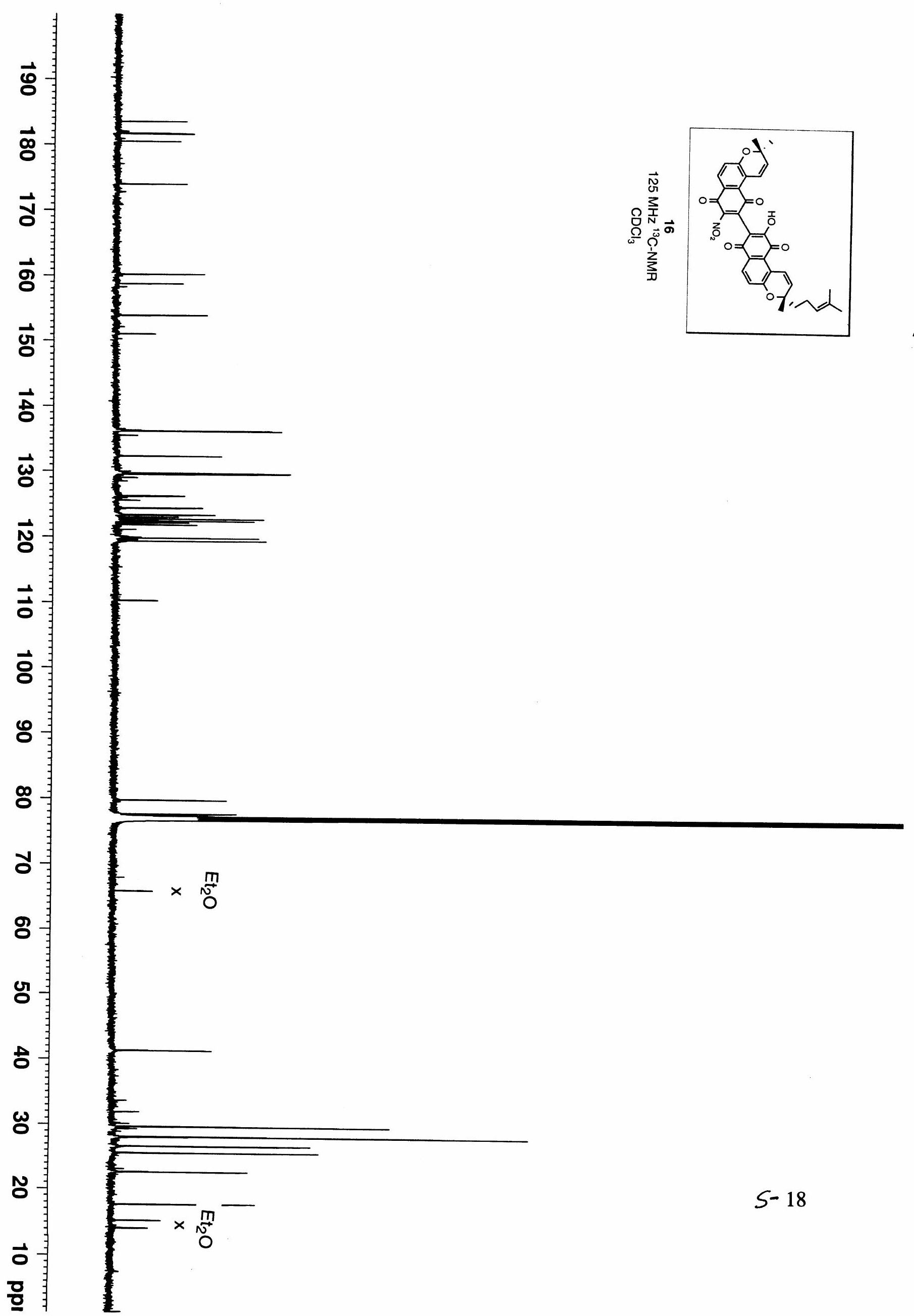




\section{Assignments of ${ }^{1} \mathrm{H}$ and ${ }^{13} \mathrm{C}$ NMR signals for compound 15:}

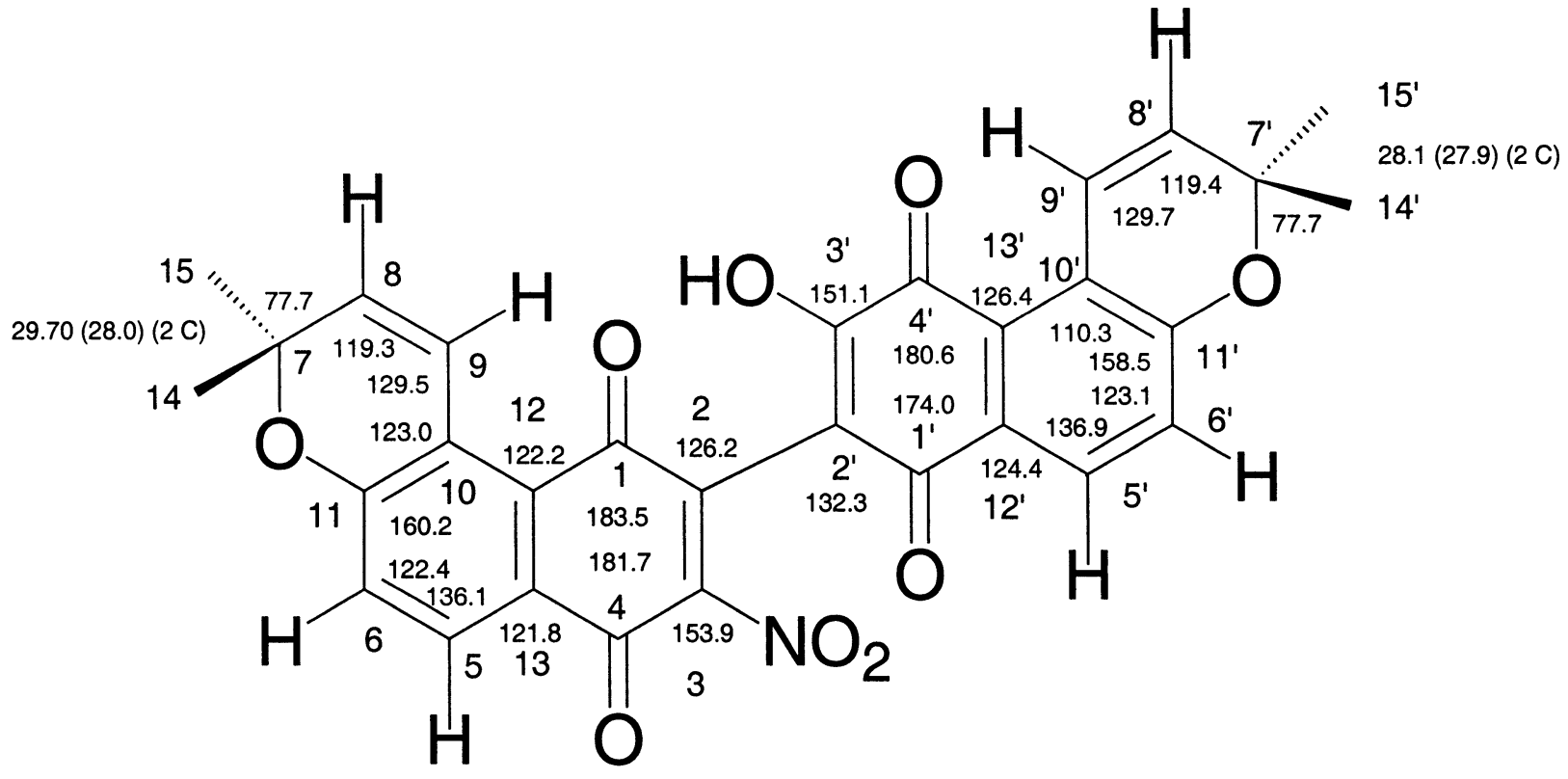

Compound 15 with ${ }^{13} \mathrm{C}$ NMR peak assignments in ppm

\section{${ }^{1} \mathrm{H}$ NMR (300 MHz, $\left.\mathrm{CDCl}_{3}\right)$ :}

$1.49(\mathrm{~s}, 12 \mathrm{H})$ for $4 \times \mathrm{CH}_{3}$ at $\mathrm{C}_{14}, \mathrm{C}_{15}, \mathrm{C}_{14}{ }^{\prime}$ and $\mathrm{C}_{15}{ }^{\prime}$;

$5.97(\mathrm{~d}, J=10.5 \mathrm{~Hz}, 1 \mathrm{H}), 6.04(\mathrm{~d}, J=10.5 \mathrm{~Hz}, 1 \mathrm{H}), 7.58(\mathrm{~d}, J=10.2 \mathrm{~Hz}, 1 \mathrm{H}), 7.73(\mathrm{~d}, J=10.5 \mathrm{~Hz}, 1 \mathrm{H})$

for $4 \times \mathrm{Csp}^{2}-\mathrm{H}_{\text {at }} \mathrm{C}_{8}, \mathrm{C}_{9}, \mathrm{C}_{8}{ }^{\prime}$ and $\mathrm{C}_{9}{ }^{\prime}$

$7.14(\mathrm{~d}, J=7.8 \mathrm{~Hz}, 1 \mathrm{H}), 7.17(\mathrm{~d}, J=8.4 \mathrm{~Hz}, 1 \mathrm{H}), 8.00(\mathrm{~d}, J=8.4 \mathrm{~Hz}, 1 \mathrm{H}), 8.07(\mathrm{~d}, J=8.4 \mathrm{~Hz}, 1 \mathrm{H})$

for $4 \times \mathrm{Csp}^{2}-\mathrm{H}$ at $\mathrm{C}_{5}, \mathrm{C}_{6}, \mathrm{C}_{5}{ }^{\prime}$ and $\mathrm{C}_{6}{ }^{\prime}$

7.90-8.00 (s, br, $1 \mathrm{H}$ ) for $\mathrm{H}-\mathrm{O}$ proton $\mathrm{H}$-bonded to the carbonyl group(s).

\section{${ }^{13} \mathrm{C}$ NMR (125 MHz, $\left.\mathrm{CDCl}_{3}\right)$ :}

see the assignments of the observed signals (in ppm) shown in the structure of compound $\mathbf{1 5}$ above. Signals assigned to the minor atropisomer are given in parentheses. 


\section{Assignments of ${ }^{1} \mathrm{H}$ and ${ }^{13} \mathrm{C}$ NMR signals for compound 16:}

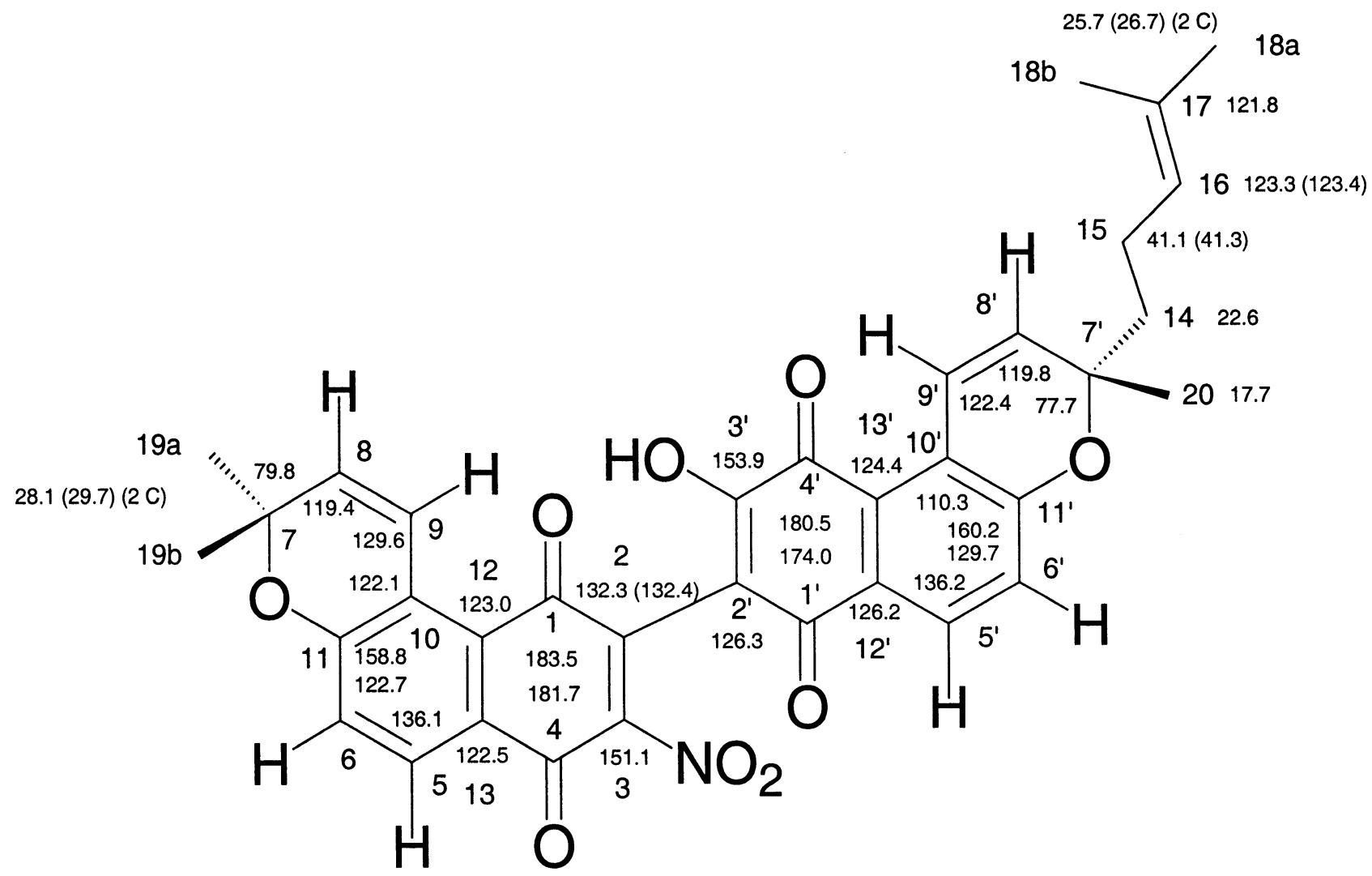

\section{Compound 16 with ${ }^{13} \mathrm{C}$ NMR peak assignments in ppm}

\section{${ }^{1} \mathrm{H}$ NMR (300 MHz, $\left.\mathrm{CDCl}_{3}\right)$ :}

$1.47(\mathrm{~s}, 3 \mathrm{H})$ for $\mathrm{CH}_{3}$ at $\mathrm{C} 20 ; 1.49(\mathrm{~s}, 6 \mathrm{H})$ for two $\mathrm{CH}_{3}$ grous at $\mathrm{C} 19 \mathrm{a}$ and $\mathrm{C} 19 \mathrm{~b}$;

$1.57(\mathrm{~s}, 3 \mathrm{H})$ and $1.66(\mathrm{~s}, 3 \mathrm{H})$ for two $\mathrm{CH}_{3}$ groups at carbons $\mathrm{C} 18 \mathrm{a}$ and $\mathrm{C} 18 \mathrm{~b}$;

1.71-1.79 $(\mathrm{m}, 2 \mathrm{H})$ and $2.05-2.13(\mathrm{~m}, 2 \mathrm{H})$ for two $\mathrm{CH}_{2}$ groups at carbons $\mathrm{C} 15$ and $\mathrm{C} 14$;

$5.08(\mathrm{t}, J=2.0 \mathrm{~Hz}, 1 \mathrm{H})$ for $\mathrm{Csp}^{2}-\mathrm{H}$ proton at carbon $\mathrm{C} 16$;

$5.97(\mathrm{~d}, J=11.1 \mathrm{~Hz}, 1 \mathrm{H}), 6.00(\mathrm{~d}, J=10.2,1 \mathrm{H}), 7.58(\mathrm{~d}, J=10.5 \mathrm{~Hz}, 1 \mathrm{H}), 7.81(\mathrm{~d}, J=10.2 \mathrm{~Hz}, 1 \mathrm{H})$ for the four $\mathrm{Csp}^{2} \mathrm{H}$ protons at carbons $\mathrm{C} 8, \mathrm{C} 9, \mathrm{C} 8$ ' and $\mathrm{C}^{\prime}$;

$7.13(\mathrm{~d}, J=8.4 \mathrm{~Hz}, 1 \mathrm{H}), 7.17(\mathrm{~d}, J=8.7 \mathrm{~Hz}, 1 \mathrm{H}), 8.00(\mathrm{~d}, J=8.4 \mathrm{~Hz}, 1 \mathrm{H}), 8.08(\mathrm{~d}, J=8.4 \mathrm{~Hz}, 1 \mathrm{H})$ for the four $\mathrm{Csp}^{2} \mathrm{H}$ protons at carbons $\mathrm{C} 5, \mathrm{C} 6, \mathrm{C} 5$ ' and $\mathrm{C} 6$ ';

7.90-8.00 (s, br, $1 \mathrm{H}$ ) for H-O proton H-bonded to the carbonyl group(s).

\section{${ }^{13} \mathrm{C}$ NMR (125 MHz, $\left.\mathrm{CDCl}_{3}\right)$ :}

see the assignments of the observed signals (in ppm) shown in the structure of compound $\mathbf{1 6}$ above. Signals assigned to the minor atropisomer are given in parentheses. 